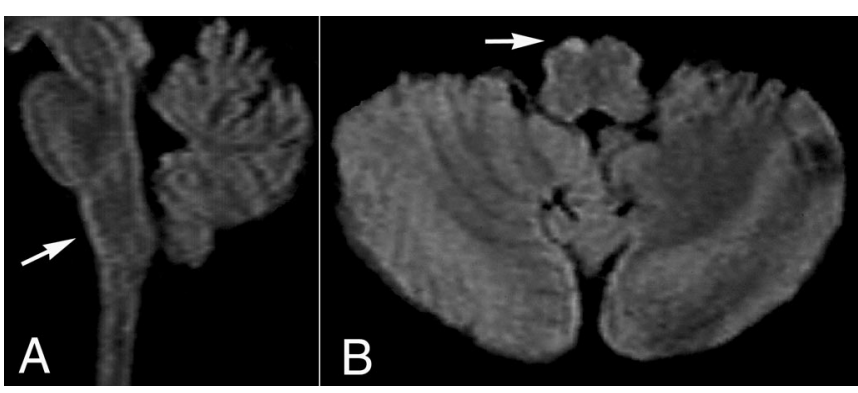

Figure. Fluid-attenuated inversion recovery MRI depiction of Wallerian degeneration of the medullary pyramidal tract (A, sagittal; $B$, axial) manifest as isolated hyperintensity (arrows).

\section{Wallerian degeneration of the corticospinal tracts}

David S. Liebeskind, MD, Philadelphia, PA

A 35-year-old woman experienced acute onset of neck pain with dysarthria and left-sided weakness. Neurologic examination revealed a right-sided Horner's syndrome, left facial palsy, and left hemiparesis. The diagnostic evaluation disclosed a spontane-

Address correspondence and reprint requests to Dr. David S. Liebeskind, Comprehensive Stroke Center and Department of Neurology, University of Pennsylvania, 3 West Gates Building, 3400 Spruce Street, Philadelphia, PA 19104-4283; e-mail: davidliebeskind@yahoo.com
Neuro Images

ous cervicocephalic dissection of the right internal carotid artery with infarction of the anterior division of the right middle cerebral artery territory. One year later she still had spasticity and mild weakness of her left upper and lower extremities.

MRI demonstrated the evolution of her right middle cerebral artery stroke with evidence of Wallerian degeneration extending throughout the right corticospinal tract from the corona radiata to the upper cervical spinal cord. Sagittal and axial fluid-attenuated inversion recovery (FLAIR) sequences illustrated hyperintensity within the pyramidal tracts descending from the pons through the medulla oblongata (figure, A and B).

Wallerian degeneration following cerebral infarction may delineate the ipsilateral corticospinal tract on MRI due to increased water content, glial proliferation, and compartmentalization of water protons associated with anterograde axonal degeneration and demyelination. Involvement of the medulla oblongata may be recognized by the characteristic selective abnormality of the medullary pyramid. Juxtaposition of the medullary pyramid with CSF may limit T2-weighted MRI in this region. ${ }^{1}$ Although diffusionweighted imaging and diffusion tensor analysis may be useful diagnostic techniques for assessment of Wallerian degeneration, ${ }^{2}$ anatomic constraints may preclude assessment of the medulla oblongata. FLAIR MRI may overcome these physical limitations and facilitate illustration of this characteristic pattern.

1. Hecht MJ, Fellner F, Fellner C, Hilz MJ, Heuss D, Neundorfer B. MRIFLAIR images of the head show corticospinal tract alterations in ALS patients more frequently than T2-, T1- and proton-density-weighted images. J Neurol Sci 2001;186:37-44.

2. Werring DJ, Toosy AT, Clark CA, et al. Diffusion tensor imaging can detect and quantify corticospinal tract degeneration after stroke. J Neurol Neurosurg Psychiatry 2000;69:269-272. 


\title{
Neurology
}

\author{
Wallerian degeneration of the corticospinal tracts \\ David S. Liebeskind \\ Neurology 2004;62;828 \\ DOI 10.1212/01.WNL.0000115396.43457.52
}

\section{This information is current as of March 8, 2004}

\section{Updated Information \& Services}

\section{References}

Subspecialty Collections

Permissions \& Licensing

Reprints including high resolution figures, can be found at: http://n.neurology.org/content/62/5/828.full

This article cites 2 articles, 1 of which you can access for free at: http://n.neurology.org/content/62/5/828.full\#ref-list-1

This article, along with others on similar topics, appears in the following collection(s):

All Cerebrovascular disease/Stroke

http://n.neurology.org/cgi/collection/all_cerebrovascular_disease_strok e

\section{Infarction}

http://n.neurology.org/cgi/collection/infarction

MRI

http://n.neurology.org/cgi/collection/mri

Information about reproducing this article in parts (figures,tables) or in its entirety can be found online at:

http://www.neurology.org/about/about_the_journal\#permissions

Information about ordering reprints can be found online:

http://n.neurology.org/subscribers/advertise

Neurology ${ }^{\circledR}$ is the official journal of the American Academy of Neurology. Published continuously since 1951, it is now a weekly with 48 issues per year. Copyright. All rights reserved. Print ISSN: 0028-3878. Online ISSN: 1526-632X.

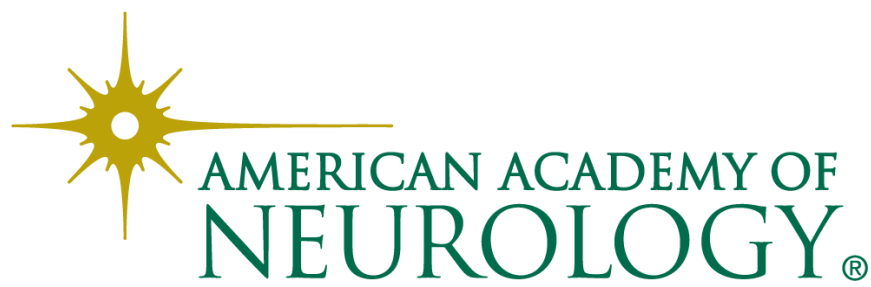

